\title{
Promoting Undergraduate Student Self-Regulation in Online Learning Environments
}

\author{
J. Brad Wandler and William J. Imbriale \\ Michigan State University
}

\begin{abstract}
Undergraduate student enrollment in online courses has steadily increased over the years and is expected to continue for the foreseeable future. The need for instructors to utilize best practices in online instruction and course design is crucial. This article presents strategies for online instructors to promote student use of self-regulated learning strategies (SRLS) in online courses, which has been associated with positive academic achievement. Implementation guidelines, empirical evidence linked to improved SRLS, and potential drawbacks are discussed.
\end{abstract}

Keywords: self-regulation, self-regulated learning, online, college, asynchronous

Wandler, J., \& Imbriale, W. (2017). Promoting undergraduate student self-regulation in online learning environments. Online Learning 21:2. doi: 10.24059/olj.v21i2.881

\section{Introduction}

Online undergraduate student enrollment is increasing in post-secondary institutions. From 2002 to 2010, the number of students taking at least one online course increased from 1.6 million students to over six million students (Allen \& Seaman, 2011). This increase has several causes including student geographic constraints, family and employment obligations, and the promulgation of increased offerings by college administration. This pattern of growth is expected to continue into the future (Allen \& Seaman, 2011).

Online learning growth is not without its challenges. Attrition rates in online learning can be twice as high as a traditional classroom format (Levy, 2007). Lack of ability to selfregulate is a significant reason for dropout rates in online courses (Lee \& Choi, 2011). This may be due in part to students not recognizing the effort and organization required to succeed in online courses. Limited self-regulatory skills may also be a contributing factor (Cho \& Shen, 2013). This article focuses on how instructors can improve their courses and reduce attrition that has historically plagued these online environments.

This article will outline the concept of a self-regulated learner, discuss why this is important in undergraduate online courses, and review strategies that instructors can use to improve the overall quality of their online classes at the collegiate level. We then focus on how to create a learning environment that promotes student use of self-regulated learning strategies. 


\section{What are Self-Regulated Learning Strategies?}

The term self-regulation is the regulation of one's thinking and actions (Zimmerman \& Schunk, 2011). For example, students may give extra thought to how they learn and the strategies they will need to succeed in college coursework. A self-regulated learner uses metacognitive, motivational, and behavioral processes to achieve a specific learning and performance goal (Zimmerman, 2008; Zimmerman, 2011). Examples of such processes include goal setting, metacognitive monitoring, help-seeking, and self-evaluation.

A self-regulated learner engages in metacognitive processes when consciously thinking about and evaluating the regulatory cognitive processes they are using (McCormick, 2003). This includes evaluating the effectiveness of certain strategies to complete a learning task, monitoring progress, and adjusting strategies if and when necessary (Baker \& Brown, 1984). Self-regulatory processes considered motivational enable a learner to initiate and sustain focused goal-directed activities while ignoring distractions or setbacks (Corno, 1994; Schunk, Meece, \& Pintrich, 2014; Zimmerman, 2011). Self-regulatory behavioral processes include the physical actions beneficial towards the completion of a task at a desired level (Zimmerman, 2011).

A student who is a self-regulated learner actively engages these processes using specific strategies called self-regulated learning strategies (SRLS) (Perry \& Rahim, 2011; Zimmerman, 1990). Examples of SRLS include receiving tutoring, keeping a study log, and emailing the instructor. A person using these strategies is engaged in what Zimmerman \& Schunk (2011) called self-regulated learning (SRL) (Zimmerman \& Schunk, 2011). All students are selfregulated learners to some degree, but not all students are necessarily strong self-regulated learners (Zimmerman, 1990). Additionally, not all self-regulated learners utilize the same strategies. One student may seek help from the instructor, whereas another student may seek help from a peer.

The distinction between processes and strategies is subtle but important. Consider the process of help-seeking. Students can actively engage in this process through many strategies. For example, the student could ask for help from a fellow classmate, a roommate, or the instructor, with each appearing as a separate strategy in which the student engages in the helpseeking process. Not all strategies effectively contribute to processes in which self-regulated learners engage. It would not be a good idea for a student to elicit help in collegiate mathematics from their eight-year-old brother who has just memorized his multiplication tables. Stronger self-regulated learners would actively seek help from someone possessing greater proficiency in the topic.

\section{Self-Regulated Learning Model}

Winne's model, Boekaerts model, and Zimmerman's model are several of the selfregulation models that have appeared throughout the years model (Panadero \& Alonso-Tapio, 2014). Zimmerman's (2011) model has been the most widely accepted, and we used it to frame this article. Zimmerman (2011) posited that SRL occurs in three cyclical phases: forethought, performance, and self-reflection (Bandura, 1997; Zimmerman, 2000; Zimmerman, 2011). Each phase consists of processes in which self-regulated learners engage. This model is cyclical. Each phase influences the processes in the next phase, and the third, in turn, influences the first all over again (see Figure 1). 


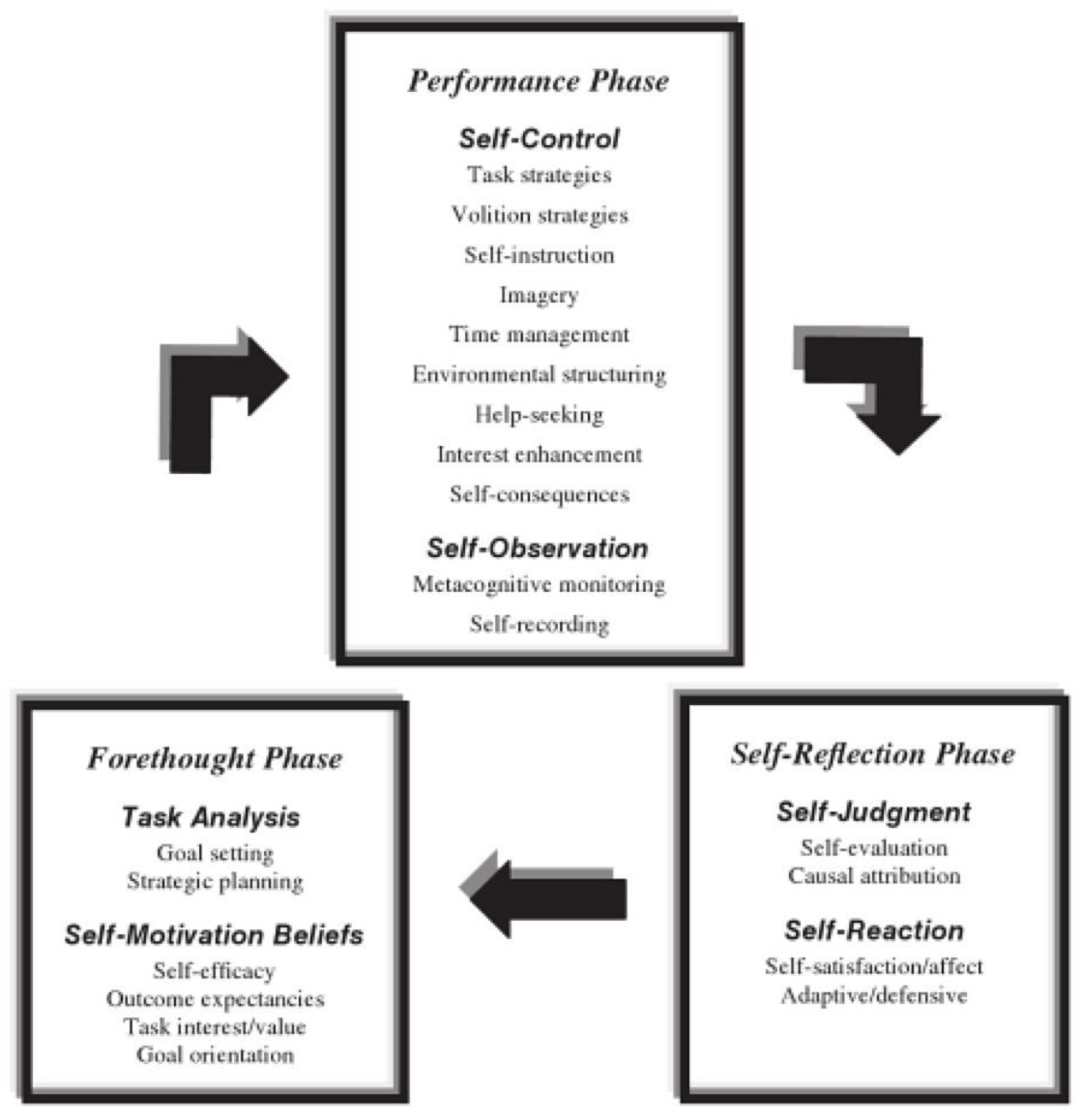

Figure 1. Phases and subprocesses of self-regulation. From "Motivating self-regulated problem solvers" by B.J. Zimmerman \& M. Campillo (2003), in The nature of problem solving (p. 239). J.E. Davidson \& R.J. Sternberg (Eds.). New York: Cambridge University Press. Copyright (2003) by Cambridge University Press.

The three phases. The forethought phase of self-regulated learning describes the processes with which students begin to initiate plans to complete a task or accomplish a goal (see Table 1). The performance phase describes the processes students employ while working towards the completion of a task or goal (see Table 2). In the self-reflection phase, students reflect on their progress towards the task or goal, or the results if they have completed the task (see Table 3). Students use that information to inform their future decisions about completing the task or goal, or beginning a new one.

Table 1

Forethought Phase Processes and Descriptions

Processes Description

$\begin{array}{cc}\text { Goal } & \text { Self-regulated learners establish short-term } \\ \text { Setting } & \text { goals serving as proximal paths to more long-term }\end{array}$




\begin{tabular}{|c|c|}
\hline $\begin{array}{l}\text { Strategic } \\
\text { Planning }\end{array}$ & $\begin{array}{l}\text { Self-regulated learners utilize strategies for } \\
\text { guiding cognition, controlling affect, and directing } \\
\text { action. }\end{array}$ \\
\hline $\begin{array}{l}\text { Self- } \\
\text { Efficacy }\end{array}$ & $\begin{array}{l}\text { Self-regulated learners believe that they are } \\
\text { capable of accomplishing the short-term goals and } \\
\text { distal outcome goals at the desired level. }\end{array}$ \\
\hline $\begin{array}{l}\text { Outcome } \\
\text { Expectancies }\end{array}$ & $\begin{array}{l}\text { Self-regulated learners believe that the task } \\
\text { presented is realistic and achievable. }\end{array}$ \\
\hline $\begin{array}{c}\text { Task } \\
\text { Interest/Value }\end{array}$ & $\begin{array}{l}\text { Self-regulated learners feel that the task is of } \\
\text { personal interest and has value. }\end{array}$ \\
\hline $\begin{array}{l}\text { Goal } \\
\text { Orientation }\end{array}$ & $\begin{array}{l}\text { Self-regulated learners are mastery goal } \\
\text { oriented. }\end{array}$ \\
\hline
\end{tabular}

Table 2

Performance Phase Processes and Descriptions

\begin{tabular}{|c|c|}
\hline Processes & Description \\
\hline $\begin{array}{l}\text { Task } \\
\text { Strategies }\end{array}$ & $\begin{array}{l}\text { Self-regulated learners use specific strategies } \\
\text { that enable the student to accomplish the task. }\end{array}$ \\
\hline $\begin{array}{l}\text { Volition } \\
\text { Strategies }\end{array}$ & $\begin{array}{l}\text { Self-regulated learners use strategies to } \\
\text { maintain their high levels of volition. }\end{array}$ \\
\hline $\begin{array}{l}\text { Self- } \\
\text { Instruction }\end{array}$ & $\begin{array}{l}\text { Self-regulated learners use statements to focus } \\
\text { mastery goal orientation and not performance goal } \\
\text { orientation. }\end{array}$ \\
\hline Imagery & $\begin{array}{l}\text { Self-regulated learners use mental images to } \\
\text { organize information and focus attention. }\end{array}$ \\
\hline $\begin{array}{r}\text { Time } \\
\text { Management }\end{array}$ & $\begin{array}{l}\text { Self-regulated learners appropriately manage } \\
\text { their time to complete the task by avoiding } \\
\text { procrastinating. }\end{array}$ \\
\hline $\begin{array}{l}\text { Environm } \\
\text { ental Structuring }\end{array}$ & $\begin{array}{l}\text { Self-regulated learners change their physical } \\
\text { surroundings to one that is more conducive to } \\
\text { completing the task. }\end{array}$ \\
\hline $\begin{array}{l}\text { Help- } \\
\text { Seeking }\end{array}$ & $\begin{array}{l}\text { Self-regulated learners seek assistance from } \\
\text { more knowledgeable others. }\end{array}$ \\
\hline Interest & Self-regulated learners view difficult tasks as \\
\hline
\end{tabular}




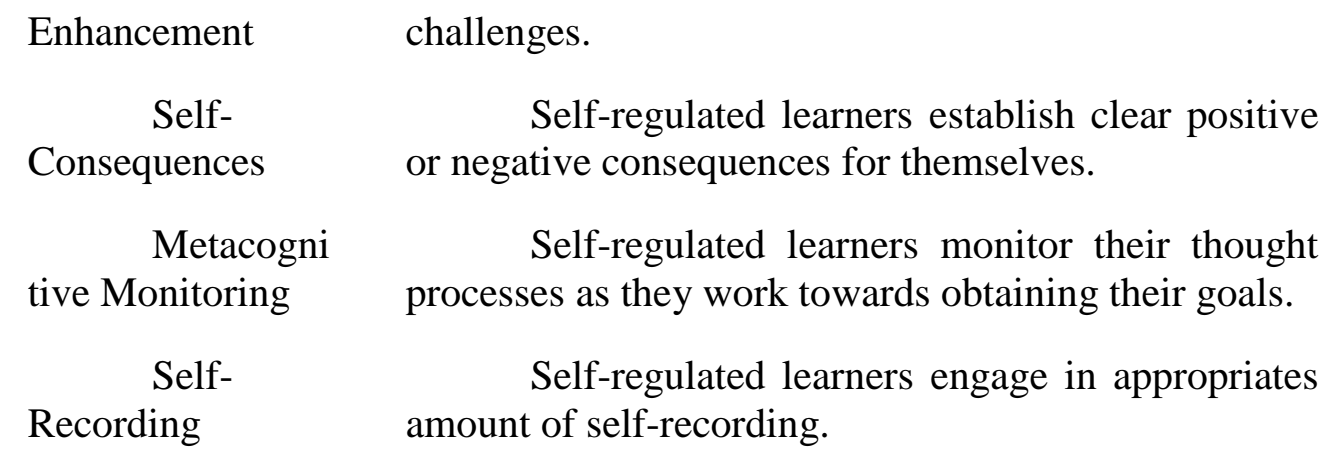

Table 3

Self-Reflection Phase Processes and Descriptions

\begin{tabular}{|c|c|}
\hline Processes & Description \\
\hline $\begin{array}{l}\text { Self- } \\
\text { Evaluation }\end{array}$ & $\begin{array}{l}\text { Self-regulated learners effectively evaluate } \\
\text { their performance during and after completing the task }\end{array}$ \\
\hline $\begin{array}{l}\text { Causal } \\
\text { Attribution }\end{array}$ & $\begin{array}{l}\text { Self-regulated learners do not attribute failures } \\
\text { to uncontrollable factors such as ability. Instead, they } \\
\text { attribute failures to insufficient effort. }\end{array}$ \\
\hline $\begin{array}{l}\text { Self- } \\
\text { Satisfaction/Affec } \\
t\end{array}$ & $\begin{array}{l}\text { Self-regulated learners do not let failure } \\
\text { discourage them, and they find satisfaction in success. }\end{array}$ \\
\hline $\begin{array}{l}\text { Adaptive/ } \\
\text { Defensive }\end{array}$ & $\begin{array}{l}\text { Self-regulated learners do not become } \\
\text { defensive and attribute failures to uncontrollable } \\
\text { causes, but become adaptive and attempt to improve } \\
\text { future performance. }\end{array}$ \\
\hline
\end{tabular}

The following examples should help illustrate the cyclical nature of these phases. Suzie, a student attending a mid-sized college, decides to set goals to help her stay motivated in an online introductory mathematics course. One of her goals is to earn an A in the course (a performance goal). To accomplish this goal, she has decided to seek help from the instructor weekly on topics that she has not fully understood. Unfortunately, at the end of the semester Suzie receives a $\mathrm{C}$ in the course. Suzie attributes the cause (i.e., causal attribution) of the grade to the strategy used (i.e., that help seeking didn't contribute to achieving her goal). In the subsequent online math course, Suzie decides not to continue this strategy.

\section{Why Promote Self-Regulated Learning Strategies (SRLS) in Online Courses?}

The above example illustrates two important points. First, students sometimes incorrectly attribute an undesirable outcome to an adopted strategy. Secondly, students who are self-efficacious in their self-regulated learning do not necessarily adopt mastery goals, which focus on mastery and understanding of content rather than performance (Ferla, Valcke, \& Schuyten, 2010). Students may not necessarily use appropriate SRLS given their academic needs, and the strategies used are not likely to improve while enrolled in online courses 
(Barnard-Brak, Paton, \& Lan, 2010). Therefore, faculty should not expect students to become better self-regulated learners simply from increased exposure to or experience with online courses.

Given that a positive association exists between self-regulated learning and academic performance in college students (Nota, Soresi, \& Zimmerman, 2004), and that students do not necessarily develop SRLS in while taking online courses, instructors should consider implementing strategies to help students promote positive SRLS. Empirical research has shown that implementing various strategies in online courses can foster SRLS in students, and that structuring of the online learning environment to promote self-regulated learning is a central component of driving successful student usage of SRLS (Barnard-Brak et al., 2010; Ferla et al., 2010; Zimmerman, 1989). Researchers have suggested that SRLS are of greater importance in online learning environments due to their more autonomous nature (Dabbagh \& Kitsantas, 2004).

\section{Strategies to Promote Student Self-Regulated Learning in Online Settings}

Students commonly enroll in online courses without knowing what effective SRLS are, what they entail, or how to utilize them effectively. Furthermore, online instructors may not be aware of ways to promote SRL in their online courses. The intent of this paper is to provide instructors with specific strategies to encourage student usage of effective SRLS. It is important to keep in mind that each strategy below will need to be adapted to the specific context in which it is employed (e.g., school, course, population). For instance, it would be more effective for online instructors to refer students to school- or department-specific resources, rather than using general statements such as 'you need to seek additional help.' Faculty also may choose to couple strategies by requiring students keep a log of their studying activity in addition to maintaining a journal. This level of customization will be essential for promoting SRLS within each individual course.

Instead of serving as an exhaustive list of ways to promote students use of SRLS, this paper will provide online instructors with evidence-based strategies that may foster SRLS aimed at improving their students' academic performance. It is important for the reader to recognize that some strategies may be more effective in certain contexts than others (Zimmerman, 1990), and faculty members need to assess each strategy's usefulness within the context of their courses. An instructor teaching only freshmen in an online course may need to provide more scaffolding than they would for students in a senior-level course. Additionally, higher achieving students tend to show better levels of self-regulation in online courses than low achieving students (Cho \& Shen, 2013). Developmental courses, or courses that traditionally have high withdrawal or failure rates, may benefit from implementation of additional strategies. To better identify the most beneficial strategies for a particular online course, an instructor may want to survey students to identify the SRLS already in use.

\section{Instructor Strategy 1: Teaching Self-Regulation Learning Strategies}

Developing online modules, sections, or content folders specifically dedicated to SRLS may prove beneficial to students who have never received guidance on these strategies or to students who have been away from the classroom for a long period of time (e.g., adult or veteran students). Online instructors should consider developing their own online readings, videos, or links to material discussing the importance of self-regulation and how to succeed in online college coursework (Hu \& Driscoll, 2013). Module topics to consider include goal setting, time 
management, test preparation, or note taking strategies for the online environment (Dabbagh \& Kitsantas, 2005). These strategies can assist students in all three phases of self-regulation (forethought, performance, and self-reflection) (Zimmerman \& Campillo, 2003).

Implementation. Most learning management systems (LMS) have functionality that allow instructors to upload videos of themselves explaining content. Written content (without video) also may prove effective. Students should be required to view these modules as part of their grade. Instructors can require students to complete an initial questionnaire or assessment based on the self-regulation modules to ensure that they have viewed the material. Information from the questionnaire or assessments could assist with early identification of students who risk failing or not completing the course. Instructors also could choose to speak with students who show low levels of confidence or knowledge on self-regulation topics and advise them accordingly. Such advisement could include the importance of study time, the level of effort expected to succeed in a course, or an offer to review their course progress regularly.

Prior research. Online modules directly addressing successful SRLS can prove beneficial in fostering the strategies they promote. Hu and Driscoll (2013) showed that web-based tutorials designed to promote successful SRLS improved academic performance and course satisfaction amongst community college students enrolled in a web-enhanced college success course. The web-based tutorials in this study focused on metacognitive, motivational, and cognitive strategies as well as their best uses specific to the course at hand (Hu \& Driscoll, 2013). Once students completed the tutorial, they submitted a study plan and self-evaluation report. These self-evaluation reports repeated every four weeks throughout the semester. The treatment group in this study showed higher overall achievement scores for those students who completed the SRL tutorial and associated tasks. Students who completed the tutorials also found significant gains in self-satisfaction and course completion rates (Hu \& Driscoll, 2013).

Additional considerations. Students may not directly see the necessity for self-regulatory modules or sections in a course (Dabbagh \& Kitsantas, 2005). A student taking an online history course may not see the point in reviewing these modules for the online classroom. This could lead to students dismissing the module and not fully reflecting on the questions at hand (Hu \& Driscoll, 2013). Faculty should emphasize the role and importance of these modules throughout the course (Dabbagh \& Kitsantas, 2004).

\section{Instructor Strategy 2: Student Study Logs}

Requiring students to keep a journal on their course progress may encourage better reflection on their SRLS (Connor-Greene, 2000; Dignath-van Ewijk, Fabriz, \& Buttner, 2015). Setting up an online spreadsheet, form, or other data entry component can allow students to enter and track their study habits (Chang, 2007). Logged information may help students to self-reflect on the efforts they have put into the course and how they can adjust their efforts if they are not meeting their academic goals. This strategy specifically targets assisting students with the selfreflective components of self-regulation, especially in the areas of self-evaluation and causal attribution (Zimmerman \& Campillo, 2003). Students who invest time tracking their progress should develop a better understanding of the links between their self-regulatory practices and results (Chang, 2007).

Implementation. Students could be required to log their goals once per week. This would aggregate the data and make it viewable to students each time they log into the course. Instructors may wish to obtain the following information weekly at minimum (adapted from Chang, 2007; Dignath-van Ewijk, et al., 2015): 
Assessing goal achievement from the prior week (open-ended)

Establishing goals for the upcoming week (open-ended)

Time allocated toward the goal for the upcoming week

Question where students can improve their learning

Question students on what would motivate them

Dates on which studying for the class took place

Assignments completed

Amount of time committed

Where study took place

With whom studying was completed

Predicted scores for upcoming tests, quizzes, or other assessments.

For an LMS that is not conducive to creating logs, the questions above can be put into a simple online questionnaire or survey for students to complete each week. Popular free survey sites include SurveyMonkey (SurveyMonkey Inc., 2015) and Google Forms (Google Inc., 2015).

Prior research. Requiring students to record their study habits and reflections on course progress can aid in fostering better self-regulatory behaviors in their current class and future classes (Connor-Greene, 2000). In a quasi-experimental design, Dignath-van Ewijk et al. (2015) found that students who used a self-regulation log (set up by the instructor) to monitor their course progress experienced significant gains in metacognitive skills, metacognitive attitude, and time management. Over $90 \%$ of students in the study recommended this type of monitoring for all freshman students (Dignath-van Ewijk et al., 2015). Chang (2007) determined that a similar logging system had an impact on performance and motivational beliefs for Taiwanese college freshmen enrolled in an online English language course, especially for students with low English proficiency. In addition to logging study hours, the system required students to predict their performance on each quiz at the completion of each learning module. This allowed students to reflect on their work leading into the quiz as well as their confidence level going into the assessment (Chang, 2007).

Additional considerations. The execution of study logs in an online course requires additional effort and planning (Dignath-van Ewijk et al., 2015). The initial setup time required, communicating expectations, and answering clarifying or technical questions for students requires a significant commitment by the faculty member (Dabbagh \& Kitsantas, 2004). It is important for the faculty member to communicate the importance of study logs and their positive impact on performance (Chang, 2007).

\section{Instructor Strategy 3: Prompting Students to Self-Regulate}

Encouraging self-regulation is more effective when done throughout a given semester, not just at the beginning (Sitzmann \& Ely, 2010). Prompting students to consider their actions in relation to their courses will provide reminders as to what is necessary to succeed in their class. This strategy emphasizes the forethought phase of self-regulation that prompts students to strategically plan how they will approach a class (Zimmerman \& Campillo, 2003). It is also a great way to help students set goals for themselves (Schunk et al., 2014).

Implementation. Instructors should consider compiling a short assessment (3-4 questions) to include on the LMS for students to complete at the beginning and end of each 
module, every week, or at another regular interval. Using a five-point Likert scale (e.g., strongly agree to strongly disagree), the questionnaire could contain several questions aimed at student self-regulatory practices. Sitzmann and Ely (2010) utilized the following questions:

Am I concentrating on learning the material?

Do I understand all the key points of the material?

Are the study strategies I'm using helping me learn the training material?

Am I setting goals to help me remember the material after I finish the course?

Would I do better on the next quiz if I studied more?

Am I setting goals to ensure I have a thorough understanding of the training material?

Do I know enough about the material to answer the questions correctly on the next assessment for this module?

The timing and frequency of prompting are key components to their impact on selfregulation. Continuous prompting throughout a semester will lead to improvements in selfregulation, learning, and retention (Sitzmann \& Ely, 2010). Only prompting self-regulatory reflection early in a given term may not have a significant effect.

Prior research. Sitzmann and Johnson (2012) analyzed the benefits of study plans on student performance in a four-hour online course. Half of the adult participants were randomly assigned to complete study plans outlining how much time, where, and when they planned to study for each module. While the planning module did not have a main effect on learning performance or attrition, the interaction effect with persistent self-regulatory prompts did enhance learning and reduce attrition (Sitzmann \& Johnson, 2012). Adding a planning component that requires students to record and reflect on study habits may help enhance their learning experience and outcomes when coupled with regular prompts throughout the term. Older students in particular also may benefit from self-regulated prompts and an overview of concepts, as these two strategies may to help them adjust to the online learning environment (Bol \& Garner, 2011).

Additional considerations. Regular prompting of students to self-regulate requires significant and careful planning (Sitzmann \& Ely, 2010). There are small yet significant details to take into consideration such as methods for data collection (e.g., surveying vs. open-ended reflection) and access to this information (e.g., available only to student, available to professor, entire class, etc.). Though the level of planning is somewhat high, the time committed by students and faculty could yield significant dividends in terms of student persistence and performance (Sitzmann \& Johnson, 2012).

\section{Instructor Strategy 4: Text Message Reminders}

Depending on the course and the student population, it may be helpful to remind students regarding their coursework outside the online learning environment or LMS. This may be particularly helpful for students who are not spending sufficient time in the online environment or who are earning low grades. While this strategy does not occur within the online learning environment, communicating outside the course environment can help redirect students who may not be managing their time effectively to succeed (Lauricella \& Kay, 2013). Using text message reminders can influence students in the performance phase of self-regulation. More specifically, this approach can assist students with their time and task management skills by helping students to focus on what needs to be accomplished in the course.

Implementation. There are several free or low-cost text message reminder services that 
instructors can utilize to communicate with students via their mobile phones. One option is to use Remind's (Remind, Inc., 2015) free education account to work with college students enrolled in the course. Students have the option to opt-in for course reminders and updates. The simple navigation screens allow the instructor to schedule reminders throughout the semester (we recommend scheduling two text messages per week). The time investment is minimal, and contacting students through a medium other than email can open the lines of communication regarding the course. Text message reminders may include any of the following:

Reminders of important dates (e.g., upcoming exams or assignment due dates).

Emphasis on which content to focus.

Reminders regarding office hours.

Motivational messages (see below).

Prior research. Sending mass texts with motivational messages may help improve student SRLS and performance. Goh, Seet, and Chen (2012) conducted an experiment where students in a treatment group received text messages twice per week encouraging them to attend lectures, workshops, and complete various assignments. Messages were used to help boost motivation, particularly for students in traditionally underperforming demographic groups. These messages had a positive impact on various measures of self-regulated learning as measured by the motivated strategies for learning questionnaire (MSLQ) (Goh et al., 2012). Students who received text messages also showed higher levels of academic performance at the end of the term (Goh et al., 2012).

Additional considerations. If the instructor would rather not send text messages regarding class or if the instructor is limited to school-owned technologies, reminders via email may be effective as well. Kim and Keller (2008) studied the effects of motivational and volitional email messages coupled with and without personal messages. The personal messages were customized to include the student's name and catered message directly to the student. Results indicated that the treatment group who received personal messages showed increased motivation and confidence over the control group (Kim \& Keller, 2008).

\section{Instructor Strategy 5: Scaffolding}

The term scaffolding refers to the providing of support mechanisms to help guide student learning (Choi, Land, \& Turgeon, 2005). Scaffolding can encourage students to seek help or approach their learning in their courses in different ways. It may also help enrich the learning experience by allowing students to dig deeper into content or further explore topics in which they are interested beyond the required content. Scaffolding may be particularly effective in the performance phase of self-regulation, especially in the areas of task strategies, time managment, interest enhancement, and help seeking.

Implementation. Scaffolding can take many forms, some of which are outlined below.

Scaffolding time expectations. Procrastination can be a significant problem for students taking online courses (Michinov, Brunot, Le Bohec, Juhel, \& Delaval, 2011). Scaffolding larger assignments over several days or several sub assignments will force students to attend to each sub assignment sometime prior to the completion of the final project. For example, if students are required to complete a term paper, the instructor could require an outline, followed by a bibliography, and then a series of rough drafts before the final paper is due. The difficulty in this approach is the added work on the instructor.

Scaffolding due dates. Another example of scaffolding that requires little to no extra 
work on the instructor is moving the due dates for assignments to several days of the week rather than having all assignments due on one day. For example, if students have a single homework set that they have to complete by a certain day. The instructor can break the homework set into sub assignments, and require these be completed on several different days of the week. This can easily be accomplished with several different assignments. This requires students to attend to the sub assignments in smaller more manageable time increments rather than allowing them the opportunity to wait to the very last day to attempt to complete all the assignments at once.

Sample work and rubrics. Posting past projects, papers, or other documents that exemplify quality work can help students understand instructor expectations. Posting sample student work may help drive new ideas and thought processes as students complete similar projects. This scaffolding technique may be enhanced by posting past work alongside a grading rubric (Dabbagh \& Kitsantis, 2005). A clear rubric can help students specify goals for themselves as they relate the rubric to their desired grade. Real-life examples of work that received high marks can help with goal setting and self-evaluation as students identify key expectations.

Online collaboration. Email or other communication capabilities allow students to get in touch with one another when they are in need of assistance, but may not necessarily want to speak with the professor. Discussion boards also allow coordination of study or other collaboration and provide a forum for students to consider other ideas while participating in the course. Discussion areas can also assist students in their scaffolding of help seeking. In other words, the discussion forum can provide an area for students to find ways to receive help regarding coursework (Dabbagh \& Kitsantas, 2005).

Outside resources. You may also choose to provide links to outside sources. Doing so may contribute to improved learning in your online course. Consider posting links to resources where students traditionally struggle in your course. For example, consider referring students to YouTube videos of different approaches to the material. Also, consider providing links to outside sources that encourage students to approach the material differently or prompt novel ideas for students to consider.

Prior research. Scaffolding can take on many forms and when implemented effectively can lead to significant results. For example, a peer questioning support framework encouraged students of varying abilities to ask collaborative questions of one another. This led to enhanced communication and questioning amongst students regarding class content (Choi et al., 2005). In another study, the use of enhanced video lessons (which included note taking, supplemental resources, and questions for consideration) showed improved learning outcomes over traditional static videos (Delen, Liew, \& Willson, 2014). Enhancements such as these are vast and diverse in approach.

Additional considerations. Since scaffolding can take on many forms in many situations, it is important for instructors to experiment with various scaffolding techniques to find what might work best with their pedagogical styles. Some may consider too much scaffolding as a form of 'hand holding' with students. Others may find, for example, that outlining milestone due dates for one assignment over the course of the semester to be the responsibility of the student. As mentioned previously, it is up to the instructor to implement strategies that are best suited to the undergraduate population enrolled in the online course.

\section{Instructor Strategy 6: Help Seeking}

Help seeking is a way for students to receive additional support from their peers or more 
knowledgeable others. In the online academic environment, help seeking typically comes in the form of information searching, formal query, or informal query (Cheng, Liang, \& Tsai, 2013). Help seeking is a critical self-control element of the performance phase of self-regulation. Students may also seek assistance through web searches using search engines, information gathering websites, textbooks, or other documents.

Implementation. Like scaffolding, fostering help seeking in your online course can take on many forms, some of which are outlined below.

Information searching. Students may encounter large amounts of irrelevant information if they rely too heavily on unguided web searches. To cut down on the use of misinformation, instructors could create a repository of vetted links to information as potential resources. Students may also share links that they find helpful on a given topic. The instructor can embed links or documents within specific assignments in order to assist students with particularly challenging content.

Formal inquiry. Students may seek help through formal query, which entails students seeking help from instructors or classmates through online resources. To foster formal query in a course, directions should be provided in clear language for students to contact the instructor. It is important for students to understand how long until they will receive responses to their questions. Having clear times of when the instructor will check emails is equally important. In other words, reduce or eliminate any barriers (implicit, technological, or other) to students accessing the instructor for help.

Fostering peer-to-peer assistance. There is also potential benefit in fostering student-to-student interaction through help seeking in online environments. For many students, communicating with another student regarding technical or academic difficulties in a course is easier than communicating such concerns to a faculty member (Abdous, He, \& Yen, 2012). Student-to-student interaction can be fostered through required online discussion boards by providing recommendations on when and how students should communicate with one another.

Prior research. Many students in online courses do not actively participate in seeking assistance from others (Cheng et al., 2013). Reasons stem from feeling embarrassed to not being provided opportunities to contact fellow peers in online courses. Students who do engage in help seeking also show higher levels of self-regulation (Cheng et al., 2013). Unfortunately, not all students will reach out to instructors with questions (Cheng et al., 2013). To overcome this issue, instructors could require students to send progress emails to the instructor, giving the instructor an opportunity to respond with a personalized message. Having students send email updates would create additional opportunities for students to self-monitor, which has been shown to increase motivation and academic performance (Chang, 2007).

Additional considerations. Students who need the most help can often be the ones to seek help the least (Cheng et al., 2013). The online environment may present a barrier to some students to pursue the help they need. While the instructor may provide and encourage lines of communications for students to seek help, it may be necessary for instructors to reach out to the student to offer the needed assistance. In other words, faculty members may need to identify students who need assistance through assessments and take it upon themselves to reach out to these students, which entails more than assignment feedback.

\section{Conclusion}

Self-regulation is a construct that has been researched for decades, and more recently has become an important component of successful online teaching and learning 
(Barnard, Lan, To, Paton, \& Lai, 2009). There is an increasing need for online faculty to not only be aware of the self-regulatory challenges that students face, but also to foster appropriate strategies as they have been shown to correlate with successful academic outcomes. Utilizing the strategies outlined in this article will improve student self-regulation in your online courses as has been shown in past research. The strategies are relatively easy to implement, low in cost, and can be useful across a wide range of subjects and online formats. Given the high attrition rates in online courses (Levy, 2007), there is a need for institutions to be more purposeful in providing support for students enrolled in these courses. Empowering students with the tools needed to be successful and active learners, rather than passive sponges, will lead to a more fulfilling and productive educational experience for all.

Each context will have its own challenges to which the faculty member will need to adapt. These challenges may include the culture of the institution or department, resistance from the students, or technology challenges caused by lack of access or support. Some of the aforementioned strategies require intense time commitments outside the regular teaching of the course content. The faculty member will need to determine the amount of time they have available to commit to these improvements in the course.

It is recommended that faculty work closely with their campus instructional designer or center for teaching and learning. These individuals can help faculty build better online courses over time through several iterations. Faculty without these resources may benefit from referring to publications such as this one, looking up online tutorials, and utilizing the community of scholars increasingly available through social networks and the like.

Some students may question the need for surveys regarding study habits or effort exerted in their coursework. It will be up to instructor to respond to these concerns appropriately, perhaps citing the overall challenge inherent in the course on top of the past challenges of online coursework. Instructors may want to emphasize the need to create a supportive and helpful community in the online environment so that students do not feel isolated in their course.

\section{References}

Abdous, M., He, W., \& Yen, C. J. (2012). Using data mining for predicting relationships between online question theme and final grade. Journal of Educational Technology \& Society, 15(3), 77-88.

Allen, I. E., \& Seaman, J. (2011). Going the Distance: Online education in the United States, 2011. Babson Park, MA: Babson Survey Research Group.

Baker, L., \& Brown, A. L. (1984). Metacognitive skills and reading. In P. Pearson, R. Barr, M. L. Kamil, \& P. Mosenthal (Eds.), Handbook of Reading Research (pp. 353-394). White Mahway, NJ: Lawrence Erlbaum Associates.

Barnard, L., Lan, W. Y., To, Y. M., Paton, V. O., \& Lai, S.L. (2009). Measuring self-regulation in online and blended learning environments. The Internet and Higher Education, 12, 16.

Barnard-Brak, L., Paton, V. O., \& Lan, W. Y. (2010). Self-regulation across time of first-generation online learners. Research in Learning Technology, 18(1), 61-70.

Bol, L., \& Garner, J. K. (2011). Challenges in supporting self-regulation in distance education 
environments. Journal of Computing in Higher Education, 23, 104-123.

Chang, M. M. (2007). Enhancing web-based language learning through self-monitoring. Journal of Computer Assisted Learning, 23, 187-196.

Cheng, K. H., Liang, J. C., \& Tsai, C. C. (2013). University students' online academic help seeking: The role of self-regulation and information commitments. The Internet and Higher Education, 16, 70-77.

Cho, M., \& Shen, D. (2013). Self-regulation in online learning. Distance Education, 34, 290-301.

Choi, I., Land, S. M., \& Turgeon, A. J. (2005). Scaffolding peer-questioning strategies to facilitate metacognition during online small group discussion. Instructional Science, 33, 483-511.

Connor-Greene, P. A. (2000). Making connections: Evaluating the effectiveness of journal writing in enhancing student learning. Teaching of Psychology, 27, 44-46.

Dabbagh, N., \& Kitsantas, A. (2004). Supporting self-regulation in student-centered web-based learning environments. International Journal on E-Learning, 3, 40-47.

Dabbagh, N., \& Kitsantas, A. (2005). Using web-based pedagogical tools as scaffolds for self-regulated learning. Instructional Science, 33, 513-540.

Delen, E., Liew, J., \& Willson, V. (2014). Effects of interactivity and instructional scaffolding on learning: Self-regulation in online video-based environments. Computers \& Education, 78, 312-320.

Dignath-van Ewijk, C., Fabriz, S., \& Büttner, G. (2015). Fostering self-regulated learning among students by means of an electronic learning diary: A training experiment. Journal of Cognitive Education and Psychology, 14, 77-97.

Ferla, J., Valcke, M., \& Schuyten, G. (2010). Judgments of self-perceived academic competence and their differential impact on students' achievement motivation, learning approach, and academic performance. European Journal of Psychology of Education, 25, 519-536.

Goh, T.-T., Seet, B.-C., \& Chen, N.-S. (2012). The impact of persuasive SMS on students' selfregulated learning. British Journal of Educational Technology, 43, 624-640.

Google Inc. (2015a). Google Forms [Online data collection software]. Retrieved from http://forms.google.com.

Hu, H., \& Driscoll, M. P. (2013). Self-regulation in e-learning environments: A remedy for community college? Journal of Educational Technology \& Society, 16(4), 171-184.

Kim, C., \& Keller, J. M. (2008). Effects of motivational and volitional email messages (MVEM) 
with personal messages on undergraduate students' motivation, study habits and achievement. British Journal of Educational Technology, 39, 36-51.

Lauricella, S., \& Kay, R. (2013). Exploring the use of text and instant messaging in higher education classrooms. Research in Learning Technology, 21.

Lee, Y., \& Choi, J. (2011). A review of online course dropout research: Implications for practice and future research. Educational Technology Research and Development, 59, 593-618.

Levy, Y. (2007). Comparing dropouts and persistence in e-learning courses. Computers \& Education, 48, 185-204.

McCormick, C. B. (2003). Metacognition and learning. In I. Weiner, W. Reynolds, \& G. Miller (Eds.), Handbook of Psychology (Vol. 7, pp. 79-102). Hoboken, NJ: John Wiley \& Sons.

Michinov, N., Brunot, S., Le Bohec, O., Juhel, J., \& Delaval, M. (2011). Procrastination, participation, and performance in online learning environments. Computers \& Education, $56,243-252$.

Nota, L., Soresi, S., \& Zimmerman, B. J. (2004). Self-regulation and academic achievement and resilience: A longitudinal study. International Journal of Educational Research, 41, 198215.

Panadero, E., \& Alonso-Tapia, J. (2014). How do students self-regulate? Review of Zimmerman's cyclical model of self-regulated learning. Anales de Psicologia, 30, 450 462.

Remind Inc. (2015). Remind [Student-teacher text messaging software]. Retrieved from http://www.remind.com

Schunk, D. H., Meece, J. L., \& Pintrich, P. R. (2014). Motivation in education: Theory, research, and applications $\left(4^{\text {th }}\right.$ ed.). Boston, MA: Pearson Education.

Sitzmann, T., \& Ely, K. (2010). Sometimes you need a reminder: The effects of prompting self-regulation on regulatory processes, learning, and attrition. Journal of Applied Psychology, 95, 132-144.

Sitzmann, T., \& Johnson, S. K. (2012). The best laid plans: Examining the conditions under which a planning intervention improves learning and reduces attrition. Journal of Applied Psychology, 97, 967-981.

SurveyMonkey Inc. (2015). Survey Monkey [Online surveying]. Retrieved from http://surveymonkey.com.

Zimmerman, B. J. (1990). Self-regulated learning and academic achievement: An overview. Educational Psychologist, 25, 3-17. 
Zimmerman, B. J. (2000). Attaining self-regulation: A social cognitive perspective. In M. Boekaerts, P. Pintrich, \& M. Zeidner (Eds.), Handbook of Self-Regulation (pp. 13-39). San Diego, CA: Academic Press.

Zimmerman, B. J. (2008). Investigating self-regulation and motivation: Historical background, methodological developments, and future projects. American Educational Research Journal, 45, 166-183.

Zimmerman, B. J. (2011). Motivational sources and outcomes of self-regulated learning and performance. In B. J. Zimmerman \& D. H. Schunk (Eds.), Handbook of Self-Regulation of Learning and Performance (pp. 49-64). New York, NY: Routledge.

Zimmerman, B. J., \& Campillo, M. (2003). Motivating self-regulated problem solvers. In J.E. Davidson \& R.J. Sternberg (Eds.), The psychology of problem solving (pp. 233-262). New York, NY: Cambridge University Press.

Zimmerman, B. J., \& Schunk, D. H. (2011). Self-regulated performance: An introduction and overview. In B. J. Zimmerman \& D. H. Schunk (Eds.), Handbook of Self-Regulation of Learning and Performance (pp. 1-12). New York, NY: Routledge. 